The Bangladesh Veterinarian (2009) 26(1) : 31 - 38

\title{
Methods of drying beef and buffalo meat on meat quality
}

\author{
M. A. Malek¹, M. M. Hossain*, R. Islam and S. Akhter \\ Department of Animal Science, Faculty of Animal Husbandry, Bangladesh Agricultural \\ University, Mymensingh-2202, Bangladesh
}

\begin{abstract}
Effects of method of drying beef and buffalo meat and storage time on quality were investigated. Six treatments were applied: drying beef with salt $\left(B_{1}\right)$, drying beef without salt $\left(B_{2}\right)$, drying beef with salt and spices $\left(B_{3}\right)$, drying buffalo meat with salt $\left(B_{4}\right)$, without salt $\left(B_{5}\right)$ and with salt and spices $\left(B_{6}\right)$. Taste and smell of all samples were acceptable up to 120 days of storage. The dry matter (DM), protein, ether extract (EE) and ash content decreased with storage time. The initial DM, crude protein (CP), EE and ash content of the samples were $92.1-95.2 \%, 77.0-78.6 \%, 5.0-6.5 \%, 8.0-12.8 \%$, respectively. After 120 days of storage DM, CP, EE and ash content of the samples ranged from $87.8-89.1 \%, 72.9-74.0 \%$, 5.0-5.9\%, 7.4-9.7\%, respectively. CP and EE percentage in beef was higher than buffalo meat, but beef contained less DM and ash. At the end of storage beef dried with salt contained highest protein $(74.0 \%)$ and buffalo meat dried without salt contained lowest protein $(73.0 \%)$. There was a significant $(\mathrm{p}<0.05$ to 0.01$)$ effect of drying method, salt and spices in beef and buffalo meat. With the elapse of storage time quality of meat degraded significantly $(\mathrm{p}<0.05$ to 0.01 ). The degradation was lower in beef dried with salt than in beef dried without salt beef or beef dried with salt and spices, and buffalo meat. It is suggested that salt drying may be a useful method of meat preservation. (Bangl. vet. 2009. Vol. 26, No. 1, 31-38)
\end{abstract}

\section{Introduction}

Beef and buffalo meat are regarded as good sources of protein, vitamins and minerals, especially iron. There is a high demand of beef and buffalo meat in Bangladesh due to its palatability and good flavours (Islam, 2008).

Meat production and consumption in Bangladesh are poor. The per capita requirement and availability of meat are 12.0 and $12.6 \mathrm{~g} /$ day, respectively, which implies an $89.5 \%$ deficit (Alam, 1993). The annual meat production in Bangladesh is about 0.744 million MT where beef contributes 0.183 million MT of the total meat production (FAO, 1997). The annual production of meat was increases day by day. The annual meat production in 2004 was 1020.2 thousand tonnes (BBS, 2005), equivalent to $7.4 \mathrm{~kg}$ meat/year/person, $60.6 \%$ from cattle, $1.3 \%$ from buffalo, $8.1 \%$ from goat, $0.9 \%$ from sheep and $29.1 \%$ from chicken and duck (BBS, 2005). Livestock in Bangladesh comprises 23.2 million cattle, 0.8 million buffaloes, 29.8 million goats, 1.0 million sheep, 11.5 million chickens and 13.5 million ducks (Alam et al., 2001).

\footnotetext{
1 Program Supervisor, Food Security Program, Action Against Hunger (France), Borguna Base Office, Borguna, Bangladesh

* Correspondence: E-mail:- mmujaffarh@yahoo.com
} 
About $23 \%$ of cattle are slaughtered every year about $7 \%$ at Eid-Ul-Azha, the largest Muslim festival (Alam, 1995). It is essential to preserve the meat when it is not consumed immediately. Stakeholders and meat sellers use the drying method only for household consumption for short time. During the monsoon, it is difficult to dry the meat. A major problem associated with drying of meat is fly infestation, which deteriorates the product.

Drying of meat reduces the water content so that microbes are unable to survive (Shawkat, 2008). Drying is easier than freezing and other preserving methods. There are no reports on the physical and nutritional features of drying meat. A systematic study is needed to determine the relationship between storage time and different parameters of dried beef and buffalo meat. The present study was undertaken to find the effect of drying on the quality of beef and buffalo meat.

\section{Materials and Methods}

Sample collection and preparation

Fresh boneless beef was collected from butcher shop in "K. R. Market", Bangladesh Agricultural University (BAU), Mymensingh at $9.00 \mathrm{am}$. Fresh boneless buffalo meat was collected from "Krishi Market" Mohammadpur, Dhaka city at 6.00 am and carried in polythene bags to the laboratory. All visible fat and connective tissue were trimmed off as far as possible. The muscle was cut into small pieces, rinsed and washed with clean water to remove blood. Then $100 \mathrm{gm}$ meat samples were kept individually in plates. All of the meat pieces were mixed properly by hand. Beef samples were dried with salt $\left(B_{1}\right)$, without salt $\left(B_{2}\right)$, or with salt and spices $\left(B_{3}\right)$; and buffalo meat was dried with salt $\left(B_{4}\right)$, without salt $\left(B_{5}\right)$ and with salt and spices $\left(\mathrm{B}_{6}\right)$.

\section{Physical appearance}

The fresh beef was reddish and bright, soft, fine, firm and elastic. Natural odour and intramuscular marbling was present. The raw buffalo meat was dark reddish and less bright, moderately soft, fine, firm and elastic. Natural meaty odour was present in raw buffalo meat.

\section{Drying agents and duration}

For drying with salt, $8 \%$ salt and $0.13 \%$ potassium nitrate were added, and for drying with spices $8 \%$ salt, $5 \mathrm{ml}$ turmeric powder and $0.13 \%$ potassium nitrate were added. All the samples were dried properly. Samples were examined 0, 30, 60 and 120 days after storage.

\section{Drying with salt, without salt and with salt and spices}

For drying with salt, drying without salt, drying with salt and spices; salt, $\mathrm{KNO}_{3}$, beef and buffalo meat were mixed thoroughly in different plates. After proper mixing beef and buffalo meat were taken into six separate petridishes and kept in the oven at 
$50^{\circ} \mathrm{C}$ temperature for 7 days until proper drying. In case of drying with salt and spices, turmeric powder were used with required amount.

\section{Storage}

The samples were stored in separate polyethylene bags at room temperature up to 120 days.

\section{Proximate analysis}

Proximate analysis of crude protein, fat, ash and moisture were carried out according to the methods of AOAC (2003). All determinations were done in triplicate and the mean value was recorded.

pH measurement

The $\mathrm{pH}$ was measured using $\mathrm{pH}$ meter in meat homogenate, prepared by blending $2 \mathrm{~g}$ of meat with $10 \mathrm{ml}$ distilled water.

\section{Statistical analysis}

Data were analysed using the analysis of variance technique in MSTAT computer program with completely randomized block design (RBD). Duncan's new multiple range test (DMRT) was done to compare variations between treatments where ANOVA showed significant differences. SEM values were calculated to identify differences between means.

\section{Results and Discussion}

Chemical composition of fresh beef and buffalo meat

The DM, ash, protein and fat percentage of fresh meat are shown in Table 1 . The DM (\%) ranged from 24.4-25.6 for beef and 25.2-25.6 for buffalo meat. The CP (\%) content ranged from 21.4-21.7 for beef and 20.7-21.1 for buffalo meat. The EE (\%) content ranged from 3.0-3.2 for beef and 2.7-2.9 for buffalo meat. The ash (\%) content ranged from 0.96-1.02 for beef and 0.98-1.04 for buffalo meat. The $\mathrm{pH}$ of fresh beef and buffalo meat was 5.8 and 5.6, respectively.

Table 1. Chemical composition of fresh beef and buffalo meat

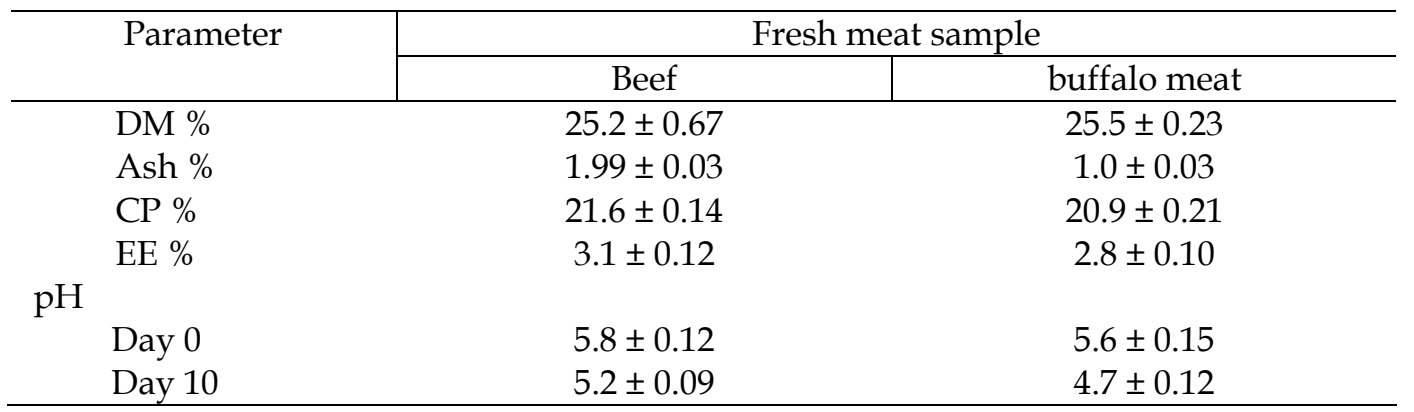

$\mathrm{DM}$ dry matter; $\mathrm{CP}$ crude protein; EE ether extract 


\section{Proximate analysis}

\section{Dry matter}

The initial dry matter was 92.1 to $95.2 \%$, and after 120 days of storage slightly lower at 87.8 to $89.2 \%$. DM decreased with storage period in all samples. The same trend was observed by Konieczny et al. (2007) who reported that DM decreased during frozen storage.

Ash

The initial value of ash ranged from 8.0 to $12.8 \%$ and after 120 days of storage it had decreased to 7.4 to $9.7 \%$ as weight basis.

\section{Crude protein}

The initial protein content was 77.0 to $78.6 \%$ and at the end of 120 days of storage had decreased to 73.0 to $74.0 \%$. The loss of protein may be related to loss of sarcoplasmic protein due to osmosis and poor water-holding capacity. The result is similar to that of Baowu et al. (1997). Konieczny et al. (2007) showed decreased protein content of frozen beef.

\section{Ether extract}

The initial ether extract content was 5.0 to $6.5 \%$ and gradually decreased. At the end of 120 days, the values were 5.0 to $5.8 \%$. The decrease of fat content is probably associated with the presence of potassium nitrate.

\section{Effects of storage time (day) on different parameters}

Effect of storage period is presented in Table 4 and 5. It shows that the initial DM was $93.6 \%$. After 120 days this value reached to $88.5 \%$. The DM of the meat sample was significantly different $(p<0.01)$ from each other at different time.

The initial ash was $10.2 \%$. At the end of storage, this value changed to $8.4 \%$ (Table 2). The ash content of the meat sample was almost similar ( $p>0.01)$ from each other at different time.

The initial CP was $77.8 \%$. At the end of 120 days this value reached to $73.5 \%$ (Table 2). The CP content of the meat sample significantly differed $(\mathrm{p}<0.01)$ from each other at different time. Protein content may be reduced during storage. The results are supported by Sarma et al. (1994); Baowu et al. (1997).

The initial EE was 5.8\%. After 120 days this value changed to 5.5\% (Table 2). The fat content of the meat sample was non-significant $(p>0.05)$ from each other at different time.

\section{Effects of preservation method on nutrient content}

Effects of different preservation methods of meat are shown in Table 3. The DM\% of all the samples were similar. The ash percentage of the samples of buffalo meat 
preserved with salt and spices (B6) was significantly higher than in those preserved with salt $(B 4)(p<0.01)$. Protein content of all samples was similar $(\mathrm{p}>0.01)$. Ether extract was highest in $\mathrm{B}_{6}(6.1 \%)$ and lowest in $\mathrm{B}_{6}(5.0 \%)$. Differences in percentage of ether extract in all samples were significant within species $(\mathrm{p}<0.01)$.

Table 2. Effect of storage time (day) on nutrient content

\begin{tabular}{|c|c|c|c|c|c|c|}
\hline \multirow{2}{*}{$\begin{array}{c}\text { Parameter } \\
(\%)\end{array}$} & \multicolumn{4}{|c|}{ Days } & \multirow[t]{2}{*}{ SEM value } & \multirow[t]{2}{*}{ Significance } \\
\hline & 0 & 30 & 60 & 120 & & \\
\hline DM & $93.6^{a}$ & $90.7^{b}$ & $89.1^{\mathrm{c}}$ & $88.5^{c}$ & 0.44897 & ** \\
\hline Ash & 10.2 & 9.0 & 8.5 & 8.4 & 0.26394 & NS \\
\hline $\mathrm{CP}$ & $77.8^{a}$ & $76.7^{b}$ & $74.3^{c}$ & $73.5^{c}$ & 0.38958 & ** \\
\hline EE & 5.8 & 5.7 & 6.0 & 5.5 & 0.08263 & NS \\
\hline
\end{tabular}

Mean with different super scripts within the same row differ significantly; ** Significant at $1 \%$ level, DM dry matter; CP crude protein; EE ether extract

Table 3. Effects of preservation methods on nutrient content

\begin{tabular}{|c|c|c|c|c|c|c|}
\hline Parameter (\%) & \multicolumn{4}{|c|}{ Sample } & \multirow[t]{2}{*}{ SEM value } & \multirow[t]{2}{*}{ Significance } \\
\hline & $B_{1}$ & $\mathrm{~B}_{2}$ & $B_{3}$ & $\mathrm{~B}_{4}$ & & \\
\hline$\overline{\mathrm{DM}}$ & 89.5 & 91.1 & 90.2 & 90.1 & 0.45 & NS \\
\hline Ash & $7.6^{c}$ & $8.9^{b c}$ & $8.6^{\mathrm{bc}}$ & $8.3^{\mathrm{b}}$ & 0.26 & $* *$ \\
\hline $\mathrm{CP}$ & 75.6 & 75.9 & 75.7 & 75.4 & 0.39 & NS \\
\hline EE & $6.1^{\mathrm{a}}$ & $5.5^{\mathrm{c}}$ & $5.9^{\mathrm{b}}$ & $5.8^{\mathrm{b}}$ & 0.08 & $* *$ \\
\hline
\end{tabular}

Mean with different superscripts within same row differ significantly; ** Significant at $1 \%$ level, NS = Non significant; $B_{1}$ beef treated with salt, $B_{2}$ without salt, $B_{3}$ with salt and spices; $B_{4}$ buffalo meat treated with salt, $\mathrm{B}_{5}$ without salt, $\mathrm{B}_{6}$ with salt and spices; DM dry matter; $\mathrm{CP}$ crude protein. $\mathrm{EE}$ ether extract.

\section{Storage time and preservation method}

The interaction of storage time and preservation methods are summarized in Table 4 . With the elapse of time meat degraded significantly $(\mathrm{p}<0.01)$.

\section{Effects of species on different parameters}

The DM content of all the paired samples were not significantly different $(p>0.01)$ (Table 5). The ash content of all paired samples were significantly different $(p<0.01)$ except $B_{1}$ and $B_{4}$ (Table 5). The fat content of all paired samples were significantly different $(p<0.05$ to 0.01$)$ from each other except $B_{2}$ and $B_{5}$ (Table 5). The protein content of all paired samples were not significantly different $(p>0.01)$ from $B_{2}$ and $B_{5}$ (Table 5).

Coefficient of Determination $\left(\mathrm{R}^{2}\right)$ was used to test the hypothesis concerning the relationship between two variables and 0.05 level of' significance used as the basis for rejection of a hypothesis. 
Table 4. Interaction of sample and storage time

\begin{tabular}{|c|c|c|c|c|c|c|c|c|c|}
\hline \multirow{2}{*}{\multicolumn{2}{|c|}{$\begin{array}{l}\text { Parameter } \\
\text { periods }\end{array}$}} & \multicolumn{6}{|c|}{ Treatment } & \multirow{2}{*}{$\begin{array}{l}\text { SEM } \\
\text { value }\end{array}$} & \multirow[t]{2}{*}{ Sig. } \\
\hline & & $\mathrm{B}_{1}$ & $\mathrm{~B}_{2}$ & $\mathrm{~B}_{3}$ & $\mathrm{~B}_{4}$ & $\mathrm{~B}_{5}$ & $\mathrm{~B}_{6}$ & & \\
\hline \multirow[t]{4}{*}{$\mathrm{DM}$} & 0 & 92.1 & 94.2 & 92.7 & 93 & 94.6 & 95.2 & 0.43401 & NS \\
\hline & 30 & $88.9^{b}$ & $91.7 \mathrm{a}$ & $89.8^{\mathrm{b}}$ & $90.3^{\mathrm{ab}}$ & $91.8^{a}$ & $91.9 \mathrm{a}$ & 0.34118 & $* *$ \\
\hline & 60 & 88.7 & 89.5 & 89.6 & 89 & 89.1 & 88.9 & 0.18361 & NS \\
\hline & 120 & 88.2 & 89.1 & 88.7 & 88.2 & 87.8 & 89.1 & 0.32229 & NS \\
\hline \multirow[t]{4}{*}{$\overline{\text { Ash }}$} & 0 & $8^{c}$ & $9.8^{b}$ & $9.5^{b}$ & $9.3^{\mathrm{bc}}$ & $11.6^{a}$ & $12.8^{\mathrm{a}}$ & 0.40911 & $* *$ \\
\hline & 30 & $7.7^{c}$ & $8.8^{\mathrm{b}}$ & $8.8^{\mathrm{b}}$ & $8.8^{\mathrm{b}}$ & $9.8^{a}$ & $10.1^{\mathrm{a}}$ & 0.21609 & $* *$ \\
\hline & 60 & $7.4^{\mathrm{d}}$ & $8.5^{c}$ & $8.4^{c}$ & $7.5^{\mathrm{d}}$ & $9.2^{\mathrm{b}}$ & $9.8^{a}$ & 0.20652 & $* *$ \\
\hline & 120 & $7.4^{\mathrm{d}}$ & $8.5^{c}$ & $8.4^{c}$ & $7.4^{\mathrm{d}}$ & $9.2^{\mathrm{b}}$ & $9.7^{\mathrm{a}}$ & 0.20416 & $* *$ \\
\hline \multirow{4}{*}{$\begin{array}{l}\text { Crude } \\
\text { protein }\end{array}$} & 0 & 78.1 & 78.6 & 77.9 & 77.6 & 77.2 & 77.0 & 0.26949 & NS \\
\hline & 30 & 76.2 & 76.3 & 76.2 & 76.7 & 76.0 & 78.9 & 0.35241 & NS \\
\hline & 60 & 74.2 & 74.9 & 74.8 & 74.0 & 73.6 & 73.9 & 0.33638 & NS \\
\hline & 120 & 74.0 & 74.0 & 73.9 & 73.0 & 72.9 & 73.0 & 0.33671 & NS \\
\hline \multirow[t]{4}{*}{$\mathrm{EE}$} & 0 & $6.5^{\mathrm{a}}$ & $5.5^{\mathrm{bc}}$ & $6.0^{\mathrm{ab}}$ & $6.0^{\mathrm{ab}}$ & $5.5^{\mathrm{bc}}$ & $5.0^{c}$ & 0.14803 & * \\
\hline & 30 & $6.2^{\mathrm{a}}$ & $5.5^{c}$ & $6.0^{\mathrm{b}}$ & $5.9^{\mathrm{b}}$ & $5.5^{c}$ & $5.0^{\mathrm{d}}$ & 0.09614 & $* *$ \\
\hline & 60 & $6.0^{\mathrm{a}}$ & $5.5^{\mathrm{b}}$ & $5.9^{a}$ & $5.8^{\mathrm{a}}$ & $5.3^{\mathrm{bc}}$ & $5.1^{c}$ & 0.08255 & $* *$ \\
\hline & 120 & 5.9 & 5.4 & 5.8 & 5.7 & 5.2 & 5.0 & 0.12241 & NS \\
\hline
\end{tabular}

Means with different superscripts within same row differ significantly; ** Significant at $1 \%$ level, * Significant at 5\% level DM dry matter

Table 5. Effects of species on nutrient content

\begin{tabular}{l|c|c|c|c|c}
\hline $\begin{array}{c}\text { Parameter } \\
(\%)\end{array}$ & Samples & Beef & Buffalo meat & P-Value & $\begin{array}{c}\text { Level of } \\
\text { significance }\end{array}$ \\
\hline $\mathrm{DM}$ & $\mathrm{B}_{1}-\mathrm{B}_{4}$ & 89.5 & 90.1 & 0.129 & $\mathrm{NS}$ \\
& $\mathrm{B}_{2}-\mathrm{B}_{5}$ & 91.1 & 90.8 & 0.479 & $\mathrm{NS}$ \\
\multirow{4}{*}{ Ash } & $\mathrm{B}_{3}-\mathrm{B}_{6}$ & 90.2 & 91.3 & 0.245 & NS \\
& $\mathrm{B}_{1}-\mathrm{B}_{4}$ & 7.6 & 8.25 & 0.159 & NS \\
& $\mathrm{B}_{2}-\mathrm{B}_{5}$ & 8.9 & 9.9 & 0.026 & $*$ \\
$\mathrm{CP}$ & $\mathrm{B}_{3} \mathrm{~B}_{6}$ & 8.8 & 10.6 & 0.030 & $*$ \\
& $\mathrm{~B}_{1}-\mathrm{B}_{4}$ & 75.6 & 75.4 & 0.401 & $\mathrm{NS}$ \\
& $\mathrm{B}_{2}-\mathrm{B}_{5}$ & 75.9 & 75.0 & 0.021 & $*$ \\
$\mathrm{EE}$ & $\mathrm{B}_{3}-\mathrm{B}_{6}$ & 75.7 & 75.7 & 0.99 & NS \\
& $\mathrm{B}_{1}-\mathrm{B}_{4}$ & 6.1 & 5.8 & 0.023 & $*$ \\
& $\mathrm{~B}_{2}-\mathrm{B}_{5}$ & 5.5 & 5.4 & 0.166 & NS \\
& $\mathrm{B}_{3}-\mathrm{B}_{6}$ & 5.9 & 5.0 & 0.001 & $* *$ \\
\hline
\end{tabular}

Means with different superscripts within same row differ significantly; ** Significant at $1 \%$ level,

* Significant at $5 \%$ level, NS = Non significant; DM dry matter; $\mathrm{CP}$ crude protein; EE ether extract 


\section{Storage time and nutrient content}

Dry matter and storage time

The computed " $\mathrm{R}^{2 \text { " }}$ value for the storage time was 0.7982 (Fig. 1) indicating that the relationship between DM and storage time was significant $(p<0.01)$. It was concluded that DM had significant positive relationship with the storage time.

Ash and storage time

The computed " $\mathrm{R}^{2 \text { " }}$ value for the storage time was 0.6963 (Fig. 2). The relationship between ash and storage time was not significant.

Crude protein and storage time

The computed value of " $\mathrm{R}^{2 "}$ for the storage time was 0.8885 (Fig. 3) $(\mathrm{p}<0.01)$. Therefore, it was concluded that crude protein had a highly significant positive relationship with storage time.

Ether extract and storage time

The computed " $\mathrm{R}^{2 \text { " }}$ value for the storage time was 0.9598 (Fig. 4). The relationship was not significant.

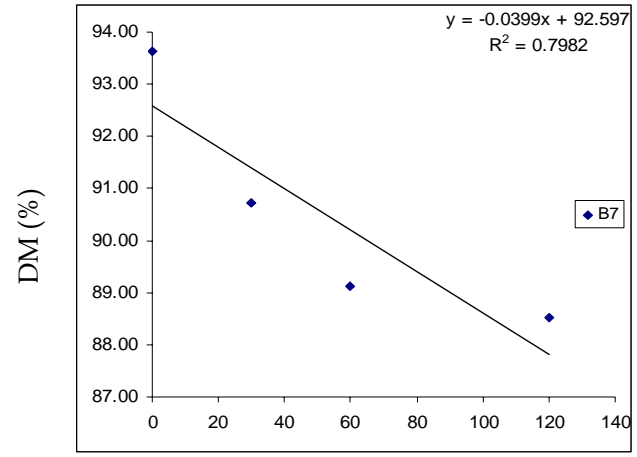

Fig. 1. Relationship between dry matter and storage time

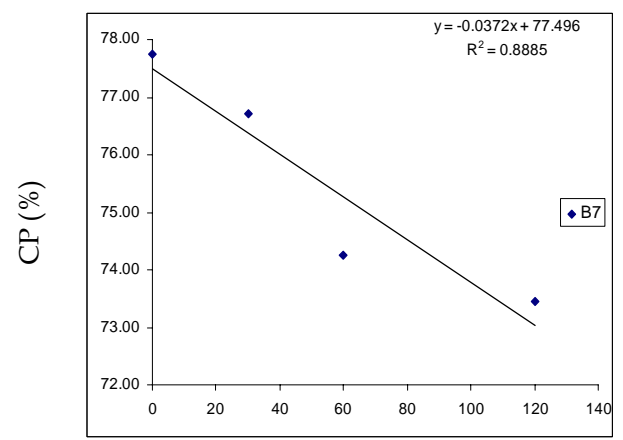

Fig. 3. Relationship between crude protein storage time

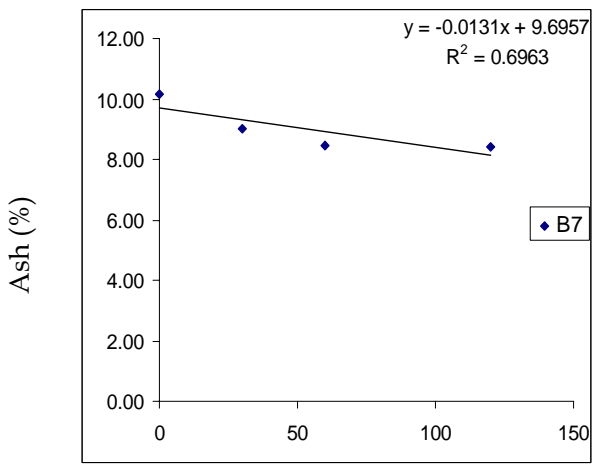

Fig. 2. Relationship between ash and storage time

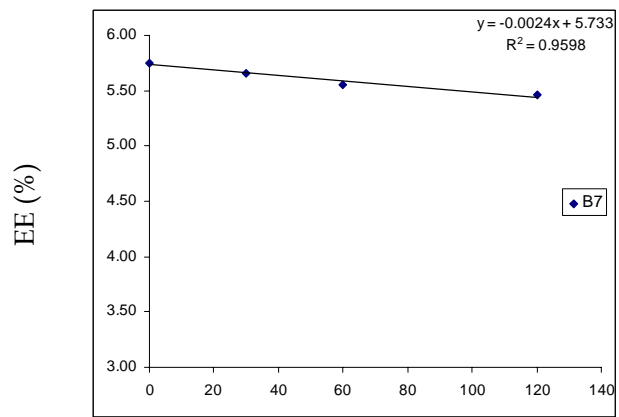

Fig. 4. Relationship between ether extract and storage time 


\section{Conclusions}

It can be concluded that storage time is closely related with the nutrient content of meat. Salt drying may be a useful method of beef and buffalo meat preservation.

\section{References}

Alam J 1993: Livestock-the sector for more investment in Bangladesh. Asian Livestock 18 77-81.

Alam J 1995: Livestock resource of Bangladesh. Present Status and Future Potential, University Press Limited. Dhaka Bangladesh.

Alam KJ, Hossain MM, Bari ASM, Chowdhury EH, Hossain AKMA, Islam MA 2001: Etiopathological Investigation of Systemic Disease in Slaughtered Black Bengal Goats. 1. Respiratory System. Bangladesh Veterinary Journal, 35 53-58.

AOAC (Association of Official Analytical Chemist). 2003. Official Methods of Analysis, Horwitz, W. (ed.), Association of Official Analytical Chemist. 17th ed., Washington DC, USA.

Wang BW; Xiong, YLL; Srinivasan, S (1997) Chemical stability of antioxidant-washed beef heart surimi during frozen storage Journal of Food Science 62 939-945.

BBS 2005: Statistical yearbook at Bangladesh. Bangladesh Bureau of Statistics. Ministry of Planning, Planning Division, Government of the Peoples Republic of Bangladesh.

BBS 2006: Statistical yearbook at Bangladesh. Bangladesh Bureau of Statistics. Ministry of Planning, Planning Division, Government of the Peoples Republic of Bangladesh.

FAO (Food and Agriculture Organization of United Nations) 1997: Production Year Book, 50. Rome, Italy.

Islam R 2008: Effect of Cuing on beef and buffen quality. MS Thesis, Department of Animal Science. Faculty of Animal Husbandry, Bangladesh Agricultural University, Mymensingh-2202.

Konieczny P, Stangierski J, Kijowski J 2007: Physical and chemical characteristics and acceptability of home style beef jerky. Meat Science $\mathbf{7 6}$ 253-257.

Sarma, J, Srikar LN, Reddy JVS 1994: Deteriorative changes in ice stored pink perch and oil sardine. Indian Journal of Marine Sciences 12 921-925.

Shawkat M 2008: Effect of sun heating on fresh or cured cattle and goat meat. MS Thesis. Department of Animal Science. Faculty of Animal Husbandry, Bangladesh Agricultural University, Mymensingh. 